\section{Australian Journal of \\ Crop Science}

AJCS

ISSN:1835-2707

\title{
Monitoring of drippers during wastewater application through statistical quality control
}

\author{
Flavio Daniel Szekut ${ }^{1 *}$, Delfran Batista dos Santos ${ }^{2}$, Carlos Alberto Vieira de Azevedo ${ }^{1}$, Marcio Antonio \\ Vilas Boas ${ }^{3}$, Márcio Roberto Klein ${ }^{1}$, Maycon Diego Ribeiro ${ }^{4}$ and Thiago Zuculotto ${ }^{3}$ \\ ${ }^{1}$ Federal University of Campina Grande, Academic Unit of Agricultural Engineering, Campina Grande, 58.429-140, \\ Paraíba, Brazil \\ ${ }^{2}$ Federal Institute of Education, Science and Technology of Bahia (IF Baiano), Senhor do Bonfim, Brazil \\ ${ }^{3}$ State University of Western Paraná (UNIOESTE/PGEAGRI), Cascavel, Brazil \\ ${ }^{4}$ Federal University of Paraná (UFPR), Jandaia do Sul, Brazil
}

\section{*Corresponding author: flaviodanielszekut@gmail.com}

\begin{abstract}
The use of alternative water sources for irrigation such as wastewaters, promotes innumerous benefits, but investigations must be conducted to minimize the negative effects of this technique. Clogging drippers are of the limitations. This study aimed to monitor the clogging of three models of labyrinth-type drippers subjected to irrigation with wastewater from treated domestic sewage, through statistical quality control using Shewhart $\bar{X}$ charts. The drippers tested were as following: Dripper Streamline 16080 model (Netafim ); Taldrip model (Naadanjain ); and Dripper Tiran 16010 model (Netafim ${ }^{\circ}$ ). The system was installed with five lateral lines per model of dripper on a bench at the field in the Brazilian semi-arid region. The system was evaluated every $36 \mathrm{~h}$ of operation at eight collection points in each lateral line, totaling thirty-three evaluations at the end of the experiment, which corresponded to a total of $1188 \mathrm{~h}$ of operation. Dripper clogging was identified by the statistical control charts with 432,540 and $360 \mathrm{~h}$ for the drippers Streamline 16080 model, Taldrip model and Tiran 16010 model, respectively, indicating the moment to apply a cleaning process. The monitoring through statistical quality control allowed simultaneously identifying the variability of the process and the reduction in flow rates, identifying the moment of clogging of the system and to carry out actions of unclog.
\end{abstract}

Keywords: Shewhart charts, biofilm, degree of clogging, uniformity coefficient, labyrinth-type drippers.

Abbreviations: D1_Dripper Streamline 16080 model from the brand Netafim; D2_Dripper Taldrip model from the brand Naadanjain ; D3_Dripper Tiran 16010 model from the brand Netafim .

Introduction

The semi-arid regions since 1960 have the largest expansion compared with other rainfed areas (Huang et al., 2016). In these regions with water scarcity, the priority of the water resource is human consumption, animal watering and then agriculture. Irrigation in these regions uses lower-quality water or alternative water resources. One of these alternatives is the use of wastewater, since it is an abundant resource that can contribute to filling the deficit between demand and availability of good-quality water (Alobaidy et al., 2010). The drip system is indicated for wastewater application and its characteristic is applying the water resource directly on the root system of the crop, which promotes reduction of contaminants in plant shoots and for the workers. However, clogging of the system is a problem that can limit the application and popularization of this technology of use of wastewaters ( $\mathrm{Li}$ et al., 2013). Monitoring irrigation systems for clogging control is performed through uniformity coefficients, as used by Zhou et al. (2015), and by the decrease of the applied flow rate or the degree of clogging, as used by Cabral de Almeida et al.
(2013). Statistical quality control is one way of monitoring processes (Montgomery, 2009). It started in the industry and spread to various areas, such as the pharmaceutical sector (Lima et al. 2006), water quality control (Kahraman \& Kaya, 2009), livestock farming (Mertens et al., 2011) irrigated agriculture (Justi et al., 2010) and irrigation with saline water (Ferreira da Silva et al., 2016). Irrigation with wastewater can be monitored by statistical quality control, through Shewhart control charts. According to Gove et al. (2013), the decisions of the chart are rapid and transparent, allowing decision-taking and the removal of particularities from the process. The use of statistical control to monitor the performance of the irrigation system with wastewater is proven by Hermes et al. (2013). These authors confirmed the use of this tool to evaluate the capacity of the system to maintain satisfactory uniformity conditions. The Shewhart control chart can identify the variability of the process and displacement of the data in relation to the mean or target, monitoring the clogging of the drippers. In this context, the effect of using wastewater from treated domestic sewage 
was monitored in three models of dripper, through the quality control chart, uniformity coefficient and degree of clogging.

\section{Results and discussion}

\section{Initial characteristics}

In the process of drip irrigation with treated domestic sewage, water quality characteristics and the internal flow conditions of each dripper model can contribute to clogging. Table 1 shows the characteristics of the wastewater used in the experiment.

Based on the quality of the analyzed wastewater (Table 1), there was an intermediate risk of clogging, according to Nakayama et al. (2006), for total coliforms and dissolved solids. The values of other elements indicated low risk of clogging.

Table 2 shows the descriptive analysis of the flow rate data obtained during the operation time of the drippers.

It should be pointed out the reduction of the mean flow rate in relation to the initial evaluation. In addition, the minimum values indicate the total clogging of the drippers.

At the end of the experiment, total clogging was observed in $0.6 \%$ of Streamline 16080 model drippers (D1) and $2.4 \%$ of Taldrip model (D2) and Tiran 16010 model (D3). According to Puig-Bargue's et al. (2010), the number of totally clogged drippers depends on the type of system (superficial or subsuperficial) and the type of emitter with the application of effluents.

The initial flow rate calculated in the first evaluation of the brand-new system is the target to be considered in the irrigation process, to construct the quality control charts.

The maximum values of flow rate are increments in the outlet flow of the drippers caused by variations in the manufacturing process or by the influence of water quality inside the pipes, as observed by Busato \& Soares (2010), who reported increment of $1 \%$ in the flow rate of the dripper subjected to irrigation with lower-quality water, in $700 \mathrm{~h}$ of use.

\section{Hydraulic performance of the drippers}

Fig 1 shows the monitoring of the drippers based on the Christiansen's uniformity coefficient and degree of clogging. At the end of the system's operation time, the degree of clogging reached mean values of $20.74,55.44$ and $70.40 \%$, respectively for Streamline 16080 model, Taldrip model and Tiran 16010 model. In studies with various drippers using wastewater, Naji et al. (2015) observed that the operational time and type of dripper have significant effect on the relative flow rate.

The degree of clogging represents the variation in the flow rate of the emitters in relation to the proposed value, which in this case is the flow rate of the brand-new drippers. Problems with reduction in flow rate using effluents are characterized by drippers, in which the internal flow structure favors the formation of biofilm, even under conditions of treatment against clogging (Katz et al., 2014). At the beginning of the process of using treated domestic sewage, the reduction in the flow rate was low, followed by a sharp increase in clogging. Li et al. (2012) reported that such initial reduction occurs around $256 \mathrm{~h}$ of operation.
In labyrinth-type drippers, the water flow passes through low-speed regions, especially in the curves and regions close to the walls. These regions are prone to deposition of small particles and, consequently, the formation and adherence of biofilm. The elimination of these regions promotes better self-cleaning capacity (Li et al., 2008).

Besides the bacterial colonization in the labyrinth, according to Gamri et al. (2014), loose fragments of the biofilm can cause clogging, because they are deposited in other parts of the dripper and block the water flow.

The uniformity coefficient reached values of $77.78,30.65$ and $22.25 \%$, respectively, for Streamline 16080 model, Taldrip model and Tiran 16010 model at the end of the experiment. Besides the reduction in flow rate values, evidenced by the degree of clogging, the CUC indicates high variability in the flow rate of the drippers along the operation time.

The relationship between the Christiansen's uniformity coefficient and the degree of clogging for the three emitters can be observed by the regression analysis in Table 3 .

There was a linear fit in regression analysis between CUC and DC for the three tested drippers, with a satisfactory coefficient of determination $\left(R^{2}\right)$. Therefore, it is possible to conclude that the reduction in flow rate is not uniform in the system, since the uniformity coefficient evidences such effect.

\section{Hydraulic monitoring through statistical quality control}

Fig 2 shows the monitoring of the flow rate of the drippers along the operation time using the Shewhart quality control chart for samples in subgroups. The calculated control limits indicate tolerance of the irrigation process around the proposed target. Points outside these limits indicate that the process is not under statistical control and show the variability of the flow rates.

The flow rate reduction observed in the control charts points to the influence of the wastewater in the drip system and its causes include the formation and fixation of biofilm. For Yan et al. (2010), the beginning of the formation and adhesion of the biofilm occurs at $96 \mathrm{~h}$ of operation, inducing the clogging process.

Water quality, when it interferes with the quality of the irrigation process, is detected by the statistical control. Hermes et al. (2015) observed points outside the control using effluent from cassava processing at $555 \mathrm{~h}$, but there were no points outside these limits using clean water.

For the dripper Streamline 16080 model (Figure 2a), from the sample 13 on, corresponding to $432 \mathrm{~h}$ of operation, the irrigation process with domestic sewage effluent exceeded the lower control limit, indicating the interference of clogging in the application quality of the drippers. For this operation time, the reduction in flow rate in relation to the target was equal to $3.87 \%$.

The quality control chart demonstrates, for the flow rates of the dripper Taldrip model (Figure 2b), the loss of quality of the process from the sample 16 on, $540 \mathrm{~h}$ of operation. At this time, the reduction in flow rate was equal to $4.35 \%$. For the dripper Tiran 16010 model (Figure 2c), the loss of quality in the process occurred at $5.46 \%$ of reduction in the target flow rate, corresponding to $360 \mathrm{~h}$ of operation. Among the three drippers, Tiran 16010 model obtained the 
Table 1. Physicochemical and biological characterization of the wastewater used

\begin{tabular}{|c|c|}
\hline Physicochemical parameters & Wastewater \\
\hline Electrical conductivity (mmho $\mathrm{cm}^{-1}$ at $25^{\circ} \mathrm{C}$ ) & 2139.0 \\
\hline 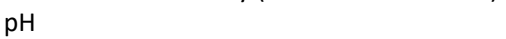 & 7.6 \\
\hline Aluminum $\left(\mathrm{mg} \mathrm{L}^{-1}\right)$ & 0,09 \\
\hline Calcium ( $\left.\mathrm{mg} \mathrm{L}^{-1}\right)$ & 48.0 \\
\hline Sodium ( $\left.\mathrm{mg} \mathrm{L}^{-1}\right)$ & 234.7 \\
\hline Magnesium (mg L $\left.{ }^{-1}\right)$ & 37.2 \\
\hline Potassium (mg L $\left.{ }^{-1}\right)$ & 60.6 \\
\hline Total Iron (mg L ${ }^{-1}$ ) & 0.08 \\
\hline Chloride (mg L $\left.{ }^{-1}\right)$ & 388.7 \\
\hline Silica $\left(\mathrm{mg} \mathrm{L}^{-1}\right)$ & 6.2 \\
\hline Total Dissolved Solids at a $180{ }^{\circ} \mathrm{C}\left(\mathrm{mg} \mathrm{L}^{-1}\right)$ & 1160.0 \\
\hline \multicolumn{2}{|l|}{ Biological Parameters } \\
\hline Total Coliforms (CFU) & 10112.0 \\
\hline
\end{tabular}
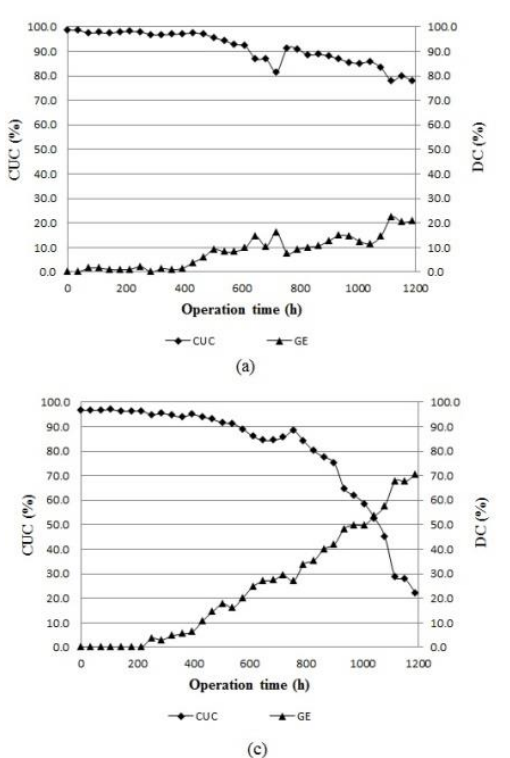

(c)

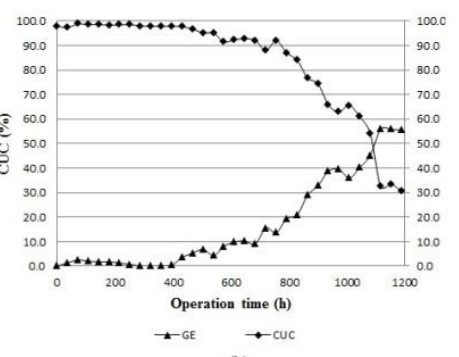

(b)

Fig 1. Hydraulic performance, Christiansen's uniformity coefficient (CUC) and degree of clogging (DC) for drippers Streamline 16080 model (a), Taldrip model (b) and Tiran 16010 model (c).

Table 2. Descriptive statistics of the flow rates of the drippers.

Dripper Initial Flow Rate $\left(\mathrm{Lh}^{-1}\right) \quad$ Mean $\left(\mathrm{Lh}^{-1}\right) \quad$ Standard Deviation Coefficient of Variation (\%) Minimum $\left(\mathrm{Lh}^{-1}\right) \quad$ Maximum $\left(\mathrm{Lh}^{-1}\right)$

\begin{tabular}{lllllll}
\hline D1 & 1.45 & 1.32 & 0.212 & 15.96 & 0.00 & 1.65 \\
D2 & 1.57 & 1.30 & 0.400 & 30.58 & 0.00 & 1.71 \\
D3 & 1.90 & 1.41 & 0.521 & 36.64 & 0.00 & 2.10 \\
\hline
\end{tabular}

D1 - Streamline 16080 model; D2 - Taldrip model; D3 - Tiran 16010 model.
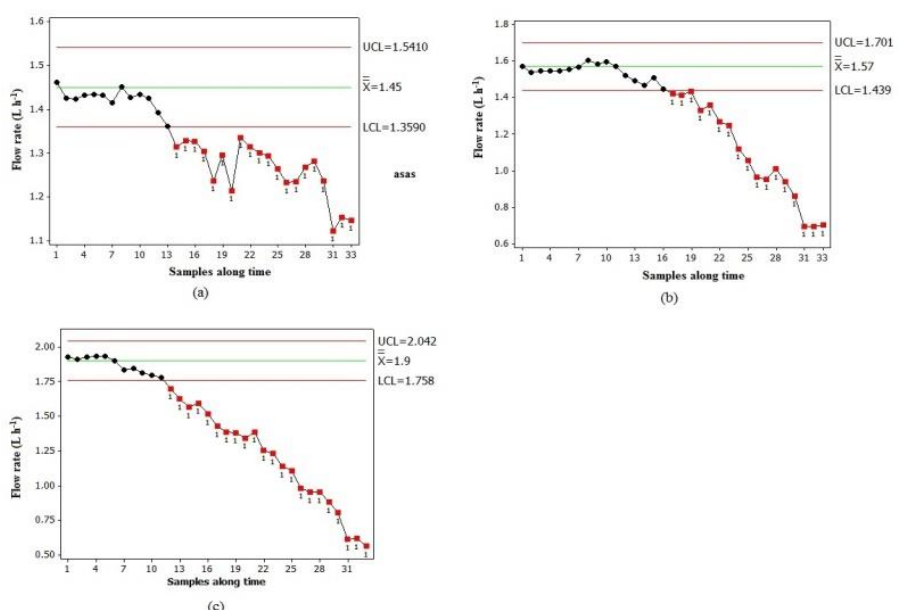

Fig 2. Shewhart quality control charts for the monitoring of flow rates of the drippers Streamline 16080 model (a), Taldrip model (b) and Tiran 16010 model (c). 
Table 3. Regression analysis between Christiansen's uniformity coefficient (CUC) and the degree of clogging (DC).

\begin{tabular}{llc}
\hline Dripper & Equation & $\mathrm{R}^{2}$ \\
\hline D1 & CUC $=99.07-0.94 D C$ & 0.92 \\
D2 & CUC $=101.60-1.08 D C$ & 0.95 \\
D3 & CUC $=103.30-0.89 D C$ & 0.87 \\
\hline D1 - Streamline 16080 model; D2 - Taldrip model; D3 - Tiran 16010 model. F test at 5\% significance level.
\end{tabular}

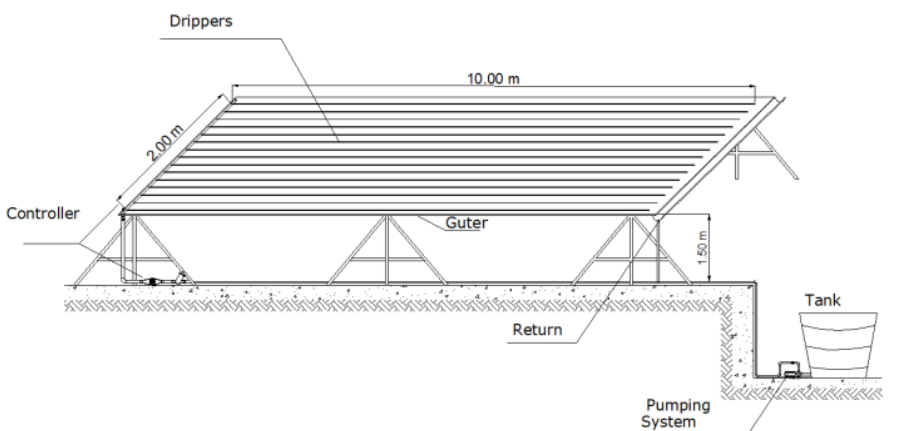

Fig 3. Layout of the irrigation system installed on the bench at the field, with control head and pumping system.

shortest time of operation without exceeding the quality control limits. The operation time under statistical control was different between the drippers and Taldrip model stood out with the longest time. As observed, this dripper obtained, at the end of the experiment, degree of clogging and Christiansen's uniformity coefficient of $55.44 \%$ and $30.65 \%$, respectively (Figure $1 \mathrm{~b}$ ). Although the statistical control was maintained for a longer operation time, the clogging was severe along the use of treated sewage. The dripper Streamline 16080 model obtained the second longest operation time under statistical control and, at the end of the $1188 \mathrm{~h}$, the lowest degree of clogging among the tested drippers. According to these characteristics, there was a combined monitoring of the variability of the process and the displacement of the flow rate in relation to the target mean, constituting an effective form to control the hydraulic performance in irrigation systems that use lowerquality water. In this context, it can be concluded that the monitoring of dripper clogging using the quality control chart indicates the application of an unclogging process from 432,540 and $360 \mathrm{~h}$ of operation for the drippers Streamline 16080 model, Taldrip model and Tiran 16010 model, respectively. With the application of an effective unclogging process, the hydraulic performance could be normalized and the flow rates could be within the limits of tolerance of the statistical control. In studies on water quality, Smeti et al. (2007) concluded that the statistical control allows the investigation of the process and the application of corrective actions before quality problems accumulate. The quality control allowed to observe not only the variability of the process through the uniformity coefficients, but also the displacement of the flow rate in relation to the proposed mean or target, evidenced by the degree of clogging. Thus, quality control charts constitute a combined form of monitoring flow rate in irrigation systems for the diagnosis of problems related to dripper clogging.

\section{Materials and methods}

\section{Experiment conduction}

The experiment was carried out on a test bench installed at the field, in order to be under the influence of the Brazilian semi-arid climate.
The bench was built at the National Institute of the SemiArid Region (INSA), located in the municipality of Campina Grande-PB, Brazil, at geographic coordinates of 70 16' 20" S and $35^{\circ} 56^{\prime} 29^{\prime \prime} \mathrm{W}$ and altitude of $550 \mathrm{~m}$. Accorging to Köppen's classification, the climate of the region is tropical, with rains in the autumn and drought periods in the rest of the year, referred to as $A s$.

The wastewater used in the experiment came from an anaerobic sewage treatment station (STS), which operates with the sewage produced by the INSA.

The main clogging components of the water were physicochemically and biologically characterized, at the Reference Laboratory in Desalination (LABDES) of the Federal University of Campina Grande - UFCG.

Three models of in-line labyrinth-type drippers were selected for the experiment, for being prone to clogging by lower-quality water. Another point considered in the choice was that these drippers are used in systems of the Brazilian semi-arid region, especially in the region of the municipalities of Mossoró-RN and Petrolina-PE.

The selected drippers were: Streamline 16080 model from the brand Netafim, referred to as D1, with nominal flow rate of $1.60 \mathrm{~L} \mathrm{~h}^{-1}$ at pressure of $100 \mathrm{kPa}$, at spacing of $0.30 \mathrm{~m}$ between emitters; Taldrip model from the brand Naadanjain , referred to as D2, with flow rate of $1.70 \mathrm{~L} \mathrm{~h}^{-1}$ at pressure of $100 \mathrm{kPa}$ and spacing of $0.20 \mathrm{~m}$; and Tiran 16010 model from the brand Netafim , referred to as D3, with flow rate of $2.00 \mathrm{~L} \mathrm{~h}^{-1}$ at pressure of $100 \mathrm{kPa}$ and spacing of 0.40 $\mathrm{m}$.

The installed system had a controller with 120-mesh disc filter (IRRITEC $\left.{ }^{\circledR}\right)$; opening valve; hydrometer (LAO $\left.{ }^{\circledR}\right)$; glycerin-filled manometer $\left(\mathrm{GE}^{\circledR}\right)$ and pressure controller $\left(B E R M A D^{\circledR}\right)$ to control the inlet pressure, fixed at $100 \mathrm{kPa}$. After irrigation, return gutters conveyed the wastewater to a tank in a recirculation procedure.

Figure 3 shows a layout of the bench. The drippers were installed at the same level along a length of $10.00 \mathrm{~m}$, the minimum distance for the model of dripper with longest spacing to have twenty-five emitters, the value recommended by the Brazilian norm ABNT/NBR ISO 926:2006, for tests with emitters. The bench was $2.00-\mathrm{m}$ wide and 1.50-m high. 
Five lateral lines were evaluated for each model of dripper. In each lateral line, eight points of collection were selected, following a hydraulic distribution of choice. The volumes were sampled in the first dripper, in the second one, at $1 / 7$ of number of drippers, $2 / 7,3 / 7,4 / 7,5 / 7,6 / 7$ and in the last dripper, according to the methodology of Denículi et al. (1980).

The evaluations consisted in the collection of volumes of water using collectors for a period of $4 \mathrm{~min}$ in each selected point. Then, the values were measured in graduated cylinders for the calculation of the flow rate per dripper.

The first evaluation of the system, brand-new, was performed with good-quality water and represents the initial flow rate, considered as the historic mean/quality target for the construction of the control charts. Subsequently, wastewater was applied and the evaluations were performed every $36 \mathrm{~h}$ of operation. The system remained turned on for $12 \mathrm{~h}$ a day.

\section{Hydraulic performance of the drippers}

The monitoring of the irrigation systems for prevention or remediation of problems that affect the applied water depth is performed based on the hydraulic performance of the emitter (Patil et al., 2013). Uniformity coefficient and degree of clogging are widely used for performance assessment.

Thirty-three evaluations were performed, corresponding to the time of $1188 \mathrm{~h}$, for the probable clogging of the system of $1000 \mathrm{~h}$, observed by Liu \& Huang (2009). For each evaluation, the Christiansen's uniformity coefficient (CUC) and degree of clogging were calculated according to Equations 1 and 2.

$$
C U C=100\left(1-\frac{\sum_{i=n}^{n}\left|q_{i}-\bar{q}\right|}{n \bar{q}}\right)
$$

Where:

$q_{i}$ - Flow rate of the tested emitter, $\mathrm{L} \mathrm{h}^{-1}$;

$\bar{q}$ - Mean flow rate of the emitters, $\mathrm{L} \mathrm{h}^{-1}$ : and,

CUC - Christiansen's uniformity coefficient, \%.

$$
D C=\left(1-\frac{q_{\text {used }}}{q_{\text {initial }}}\right) 100
$$

Where:

$q_{\text {used }}$ - Mean flow rate of the drippers, when used, $\mathrm{L} \mathrm{h}^{-1}$;

$q_{\text {initial }}$ - Mean flow rate of the drippers, when new, $\mathrm{L} \mathrm{h}^{-1}$; and,

DC - Degree of Clogging, \%;

\section{Quality control charts}

For the quality control chart, the data are plotted around the mean of the process. For the process of irrigation with lower-quality water and risk of clogging, the mean would indicate an already altered flow rate. Thus, a historic mean/target was fixed, determined by the first evaluation of the brand-new drippers.

This historic mean considered the use of the drippers with good-quality water, without alterations in the flow rates along the operation period. Thus, it is possible to observe the change of flow rate in relation to the mean and the variability of the samples in the irrigation with lower-quality water.

In the Shewhart $\bar{X}$ statistical control chart, three lines are drawn; a medium line (mean of the process or target) and the lines identifying the lower and upper control limits. Variations in the process that exceed the lower and upper control limits, according to Equations 3 and 4, characterize a process outside the statistical quality control, indicating that sources of variability are acting.

$$
\begin{aligned}
U C L & =\mathrm{X}+3 \sigma \\
L C L & =\mathrm{X}-3 \sigma
\end{aligned}
$$

Where:

\section{$U C L$ - Upper Control Limit;}

$L C L$ - Lower Control Limit;

$\sigma$ - Standard deviation of the population; and,

$\mathrm{X}$ - Mean of the process.

The Shewhart $\bar{X}$ chart can be considered as resistant to small deviations of normality. In addition, these deviations cause increase in the Type I error, false alarms. However, with the increase in the size of the sample, this difference decreases (Korzenowski and Werner, 2012). False alarms for the monitoring of irrigation systems indicate an anticipated clogging.

Each evaluation is a subgroup for the construction of the control chart. Each subgroup is formed by forty values of flow rate, eight collection points in each of the five lateral lines. Thus, based on the central limit theorem, the flow rate values can be considered as in a normal distribution.

\section{Conclusion}

The monitoring of the hydraulic performance of the drippers subjected to irrigation with wastewater from treated domestic sewage, using the statistical quality control charts, determines operation times of 432,540 and $360 \mathrm{~h}$ for the application of unclogging processes in the drippers Streamline 16080 model, Taldrip model and Tiran 16010 model, respectively. The statistical quality control charts indicate the variability and the reduction in the flow rate of the drippers, simultaneously, allowing to identify the moment of clogging of the system.

\section{Conflict of interests}

The authors have not declared any conflict of interests.

\section{Acknowledgments}

To the National Institute of the Semi-Arid (INSA), the Federal Institute of Education, Science and Technology of Bahia (IF Baiano) and the Federal University of Campina Grande (UCFG), for the logistic and infrastructure support; to the Coordination for the Improvement of Higher Education Personnel (CAPES), for granting the scholarship; and to the National Council for Scientific and Technological Development $(\mathrm{CNPq})$, for the financial support through the project no. 94/2013 MEC/SETEC/CNPq. 


\section{References}

Alobaidy HMJ, AL-Sameraiy MA, Kadhem AJ, Majeed, AA (2010) Evaluation of treated municipal wastewater quality for irrigation. J Environ Prot. 1:216-225.

Busato CCM, Soares AA (2010) Desempenho de gotejadores, utilizando água de baixa qualidade química e biológica. Biosci J. 26(5):739-746.

Almeida CCDG, Silva SS, Albuquerque Filho JAC, França e Silva ÊF (2013) Susceptibilidade ao entupimento de microtubos gotejadores sob fertirrigação. Irriga. 18(3):454-470.

Denículi W, Bernardo S, Thiébaut JTL, Sediyama GC (1980) Uniformidade de distribuição de água, em condições de campo num sistema de irrigação por gotejamento. Rev Ceres. 27(150):155-162.

Silva FP, Dantas Neto J, Matos RM, Lima SC Batista dos Santos D (2016) Statistical process control in self compensating emitters using water at different saline concentrations. Afr J Agric Res. 11(30):2736-2743.

Gamri S, Soric A, Tomas S, Molle B, Roche N (2014) Biofilm development in micro-irrigation emitters for wastewater reuse. Irrig Sci. 32:77-85.

Gove AD, Sadler R, Matsuki M, Archibald R, Pearse S, Garkaklis $M$ (2013) Control charts for improved decisions in environmental management: a case study of catchment water supply in south-west Western Australia. Ecol Manage Restor. 14(2):127-134.

ermes E, Vilas Boas MA, Gomes SD, Gomes BM, Reis CF (2013) Quality control in irrigation and fertigation with cassava processing wastewater into drip system. J Food Agr Environ.11 (2):841-845.

Hermes E, Vilas Boas MA, Rodrigues LN, Melo EL, Gonçalves MP, Lins MA, Berger JS (2015) Process capacity index in drip irrigation with cassava wastewater processing. Afr J Agric Res. 10(12):1427-1433.

Huang J, Ji M, Xie Y, Wang S, He Y, Ran J (2016) Global semiarid climate change over last 60 years. Clim Dyn. 46:11311150.

Justi A L, Vilas Boas MAV, Sampaio SC (2010) Índice de capacidade do processo na avaliação da irrigação por aspersão. Eng agríc. 30(2):264-270.

Kahraman C \& Kaya I (2009) Fuzzy process capability indices for quality control of irrigation water. Stoch Environ Res Risk Assess. 23:451-462.

Katz S, Dosoretz C, Chen Y, Tarchitzky J (2014) Fouling formation and chemical control in drip irrigation systems using treated wastewater. Irrig Sci. 32:459-469.

Korzenowski A L \& Werner L (2012) Probabilidade do erro do tipo I nas cartas $X$ e $S$ de Shewhart sob não normalidade. Prod. 22(4):807-816.
Li YK, Liu YZ, Li GB, Xu TW, Liu HS, Ren SM, Yan DZ, Yang PL (2012) Surface topographic characteristics of suspended particulates in reclaimed wastewater and effects on clogging in labyrinth drip irrigation emitters. Irrig Sci. 30:43-56.

Li Y, Yang P, Xu T, Ren S, Lin X, Wei R, Xu H (2008) CFD and digital particle tracking to assess flow characteristics in the labyrinth flow path of a drip irrigation emitter. Irrig Sci. 26:427-438.

Li Y, Zhou B, Liu Y, Jiang Y, Pei Y, Shi Z (2013) Preliminary surface topographical characteristics of biofilms attached on drip irrigation emitters using reclaimed water. Irrig Sci. 31:557-574.

Lima AAN, Lima JR, Silva JL, Alencar JRB, Soares Sobrinho JL, Lima LG, Rolim Neto PJ (2006) Aplicação do controle estatístico de processo na indústria farmacêutica. Rev Ciênc Farm Básica Apl. 27(3):177-187.

Liu H \& Huang G (2009) Laboratory experiment on drip emitter clogging with fresh water and treated sewage effluent. Agric Water Manag. 96(5):745-756.

Mertens K, Decuypere E, Baerdemaeker J, Ketelaere B (2011) Statistical control charts as a support tool for the management of livestock production. J Agric Sci. 149:369384.

Montgomery DC (2009) Introdução ao controle estatístico da qualidade. Traduction: Farias AML, Flores VRLF, Laurencel LC 4 ed. Rio de Janeiro.

Naji K, Al-Mefleh, Bashabsheh I, Talozi S, Al-Issa TA (2015) Field evaluation of the performance of different irrigation emitter types using treated wastewater. Water Qual Res J Can. 50.3:240-251.

Nakayama FS, Boman BJ, Pitts D (2006) Maintenance. In: Lamm FR, Ayars JE and Nakayama FS (Ed) Microirrigation for crop production: design, operation, and management. Amsterdam, Germany, 2006.

Patil SS, Nimbalkar PT, Joshia J (2013) Hydraulic study, design $\&$ analysis of different geometries of drip irrigation emitter labyrinth. Int J Eng Adv Technol. 2(5):455-462.

Puig-Bargués J, Arbat G, Elbana M, Duran-Ros M, Barragán J, Ramírez de Cartagena, F, Lamm FR (2010) Effect of flushing frequency on emitter clogging in microirrigation with effluents. Agric Water Manag. 97:883-891.

Smeti EM, Thanasoulias NC, Kousouri LP, Tzoumerkas PC (2007) An approach for the application of statistical process control techniques for quality improvement of treated water. Desalination. 213:273-281.

Yan D, Yang P, Rowan M, Ren S, D. Pitts (2010) Biofilm accumulation and structure in the flow path of drip emitters using reclaimed wastewater. Trans ASABE. 53(3):751-758.

Zhou B, Li Y, Liu Y, Xu F, Pei Y, Wang Z (2015) Effect of drip irrigation frequency on emitter clogging using reclaimed water. Irrig Sci. 33:221-234. 